\title{
DESIGN AND ANALYSIS OF TRUCK CHASSIS
}

\author{
Mukunda Dabair \\ Asst. Professor \\ St. Martins Engineering College
}

\begin{abstract}
This work is carried out in order to know best material \& best effective cross-section for Eicher E2 TATA truck chassis by identifying restraints of high shear stresses, equivalent stresses (von mises) and deformation under high pay load. Therefore, the greater strength cross section area is needed for reducing fracture with factor of safety in design. We have taken high strength is eminent parameter, so the current dimensions of a Tata Eicher E2 (Model number.11.10) Truck is analyzed with materials AISI 4130 Steel, AISI A304 Alloy Stainless Steel and Aluminum Alloy 6061-T6 subjected to the uniform load. The many kinds of chassis are created for the 3 types of cross-sections such as C, I and Rectangular Hollow box kind cross sections. [1] The modeling is done with CATIA V5 and analysis with ANSYS 18.2 Workbench. Chassis is calculated for the stresses and deformations numerically and are evaluated through the simulation data.
\end{abstract}

Keywords: Truck chassis, C, I, Box cross section, modeling, structural analysis.

\section{INTRODUCTION}

For a vehicle chassis (base frame) is the basic part. various automobile parts such as engine, drive train, the axle assemblies together with wheels, suspension parts, brakes, steering components are supported by means of chassis. The chassis provides necessary strength for supporting the almost all vehicles components plus the payload and also maintains the vehicle rigidly and make it stiffer. [1] Chassis is the backbone of all vehicles. For any failure in chassis the whole vehicle system collapses. Also, it is noted that the replacement of chassis is not an easy task, if any failure takes place the whole chassis set up has to change and it is high economic.

The design of chassis must be cost ineffective, reduced weight, high payload, ensures vehicle safety by bearing the most awful loading circumstances. The principle in chassis design is safety parameters and reduction of weight in order to have less fuel consumption. We must know the primary loads that the vehicle structure that have to withstand. [2] These loads must be well transferred to the chassis structure so that the chassis will not be susceptible to fracture. Hence the present paper will throw lights on chassis solid material and design.
S. Pavankalyan

Asst. Professor

St. Martins Engineering College

II. KINDS OF LOADS

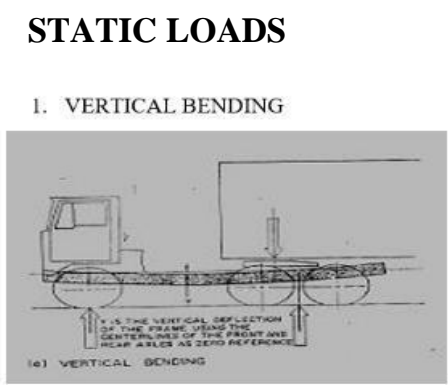

3. TORSION

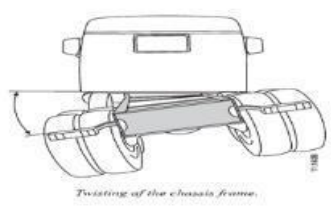

DYNAMIC LOADS

1.BRAKING

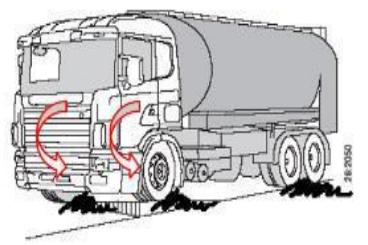

3.TIPPING

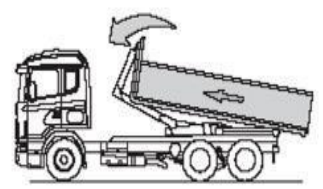

2.LATERAL BENDING

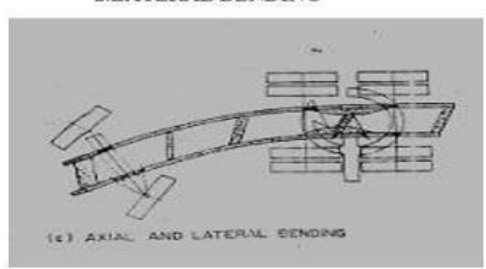

4.HORIZONATL LOZENGING

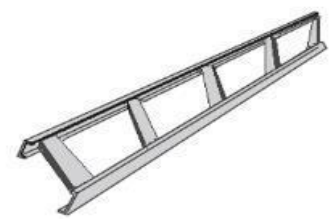

2. CORNERING

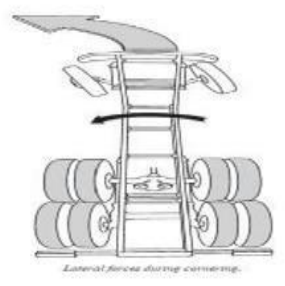

4.ARTICULATION

\section{Specification of Chassis}
- $\quad$ Chassis length $=6355 \mathrm{~mm}$
- $\quad$ Chassis width $=2250 \mathrm{~mm}$
- Chassis height $=210 \mathrm{~mm}$
- Dimension for $\mathrm{C}$ section $=210 * 76 * 6 \mathrm{~mm}$
- $\quad$ Dimension for I section $=210 * 105 * 12 \mathrm{~mm}$
- Dimension for hallow rectangular box section = $210 * 105 * 12 \mathrm{~mm}$
- Total number of cross bars $=6$ 
International Journal of Engineering Applied Sciences and Technology, 2020

Vol. 4, Issue 12, ISSN No. 2455-2143, Pages 550-553

Published Online April 2020 in IJEAST (http://www.ijeast.com)

\section{Dimension Of C, I Box Section}

ISECTION

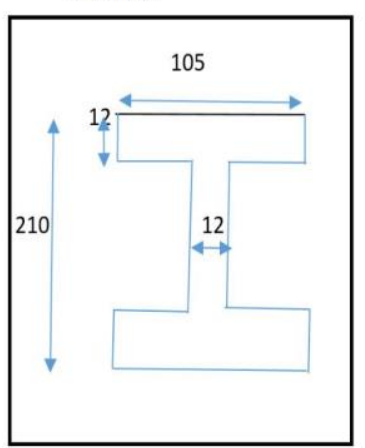

C SECTION

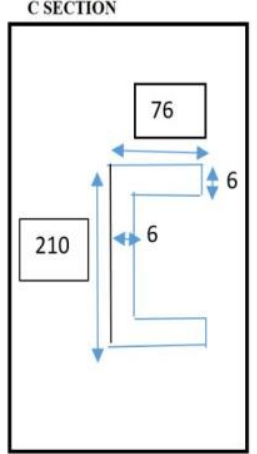

Modeling a chassis with CATIA

The geometry modeling of Stepladder chassis with C, I and Box kind model is carried with CATIA.[1]
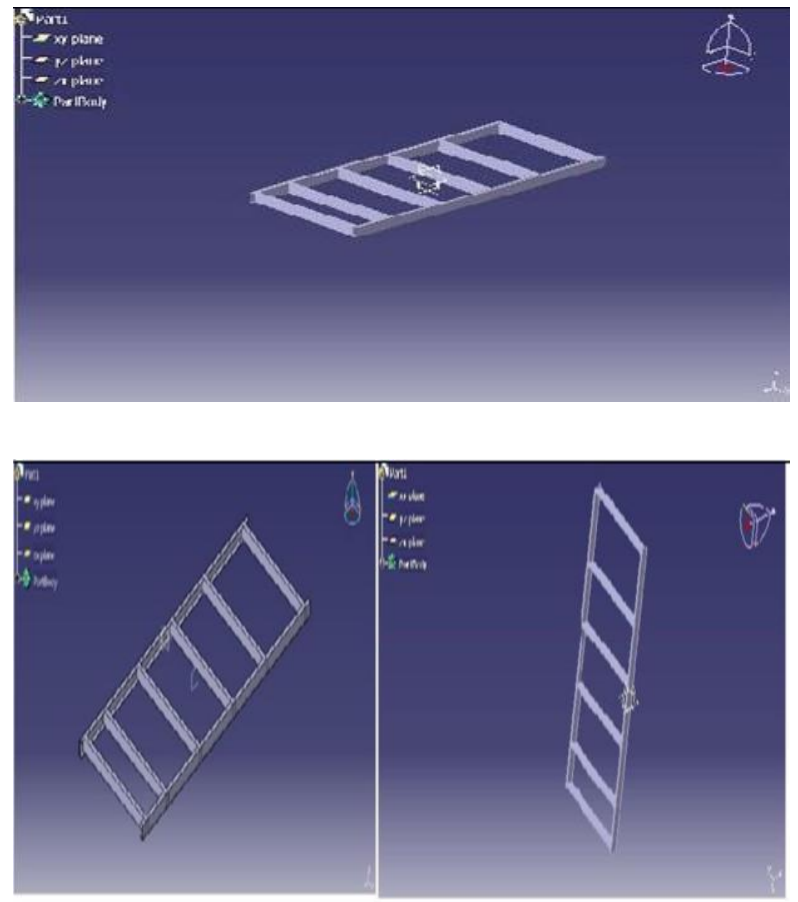

Finite element analysis of chassis

The chassis models are created and to be considered for finite element analysis by means of ANSYS. The imported model in ANSYS workbench is represented by Figure.

\section{Meshing and Boundary Situations}

The mesh of the model contains 8125 nodes and 2506 triangular elements. Static force on the chassis is taken as $10000 \mathrm{~kg}$. consider the load is uniformly distributed, i.e. the total load applied is divided along the length of chassis. [3] The fixed supports given at four edges of the model. Fixed support, force applied, meshing and boundary conditions is shown in figure below.

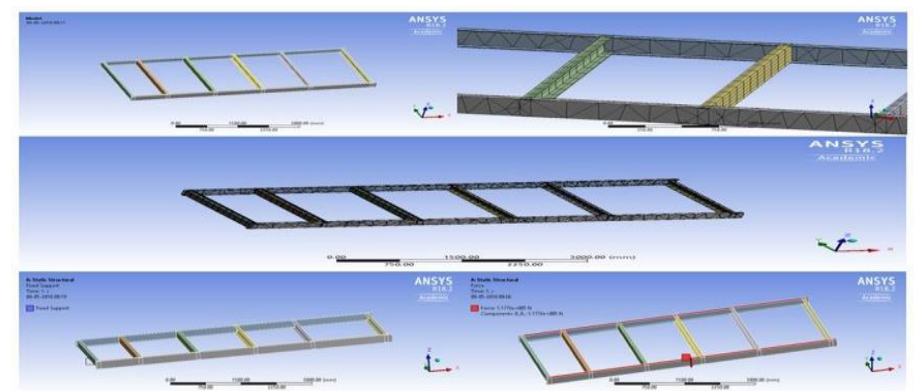

Fig. Meshing and boundary condition

\section{Structural Analysis of Step ladder Chassis}

A finite element static structural analysis of the Step ladder chassis with load acting in Y- direction is carried with 3 various c/s C, Box and I kind c/s. Also, with 3 various kinds of materials - AISI 4130 Steel, AISI A304 Stainless Steel and Aluminum Alloy 6061-T6 are used for analysis. It begins with applying fixed support and force on chassis frame. [4] The contour plots of Von mises (Equivalent) stresses distribution, Maximum Stresses and deflection for the three-cross section with three materials showing in below.

Static analysis of $\mathrm{C}$ Cross-section kind of Stepladder Chassis

\section{FOR AISI 4130 STEEL WITH C SECTION}

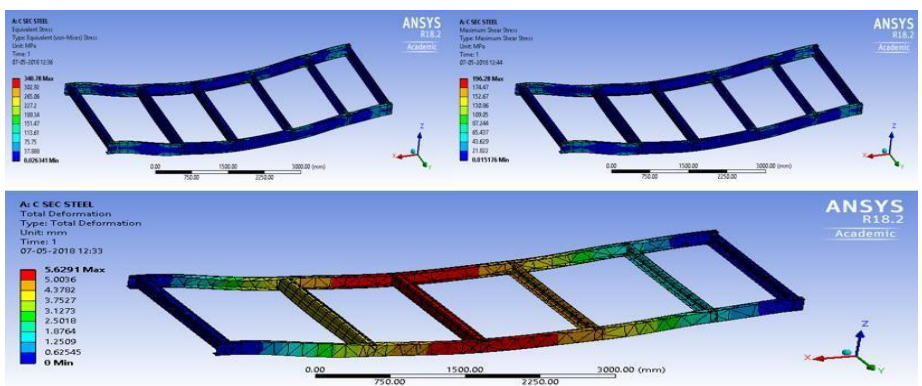

\section{FOR AISI A304 STAINLESS STEEL ALLOY WITH C SECTION}

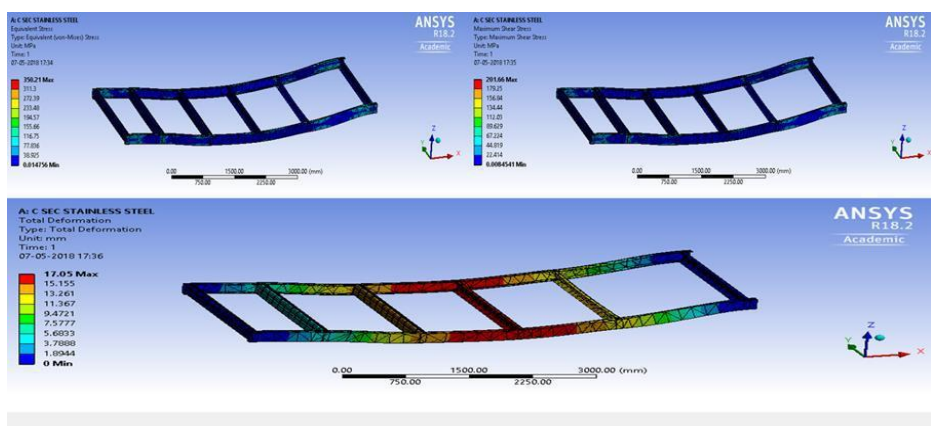


International Journal of Engineering Applied Sciences and Technology, 2020

Vol. 4, Issue 12, ISSN No. 2455-2143, Pages 550-553

Published Online April 2020 in IJEAST (http://www.ijeast.com)

3. FOR ALUMINIUM 6061-T6 ALLOY WITH C SECTION

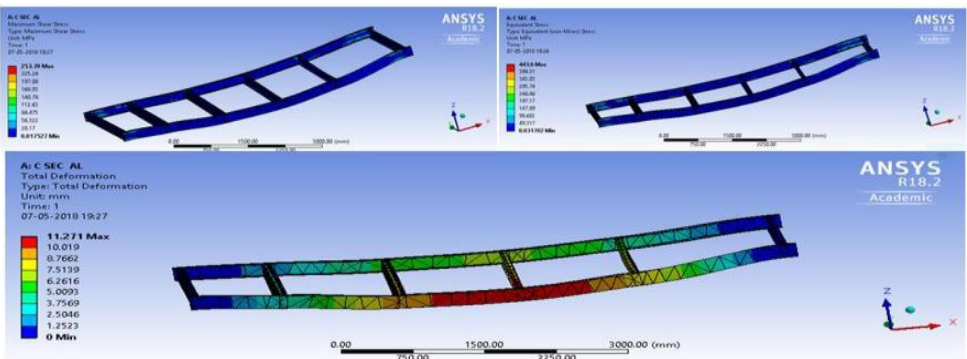

Static analysis of irectangular Box Cross-section kind of Step ladder Chassis

\section{FOR AISI 4130 STEEL WITH BOX SECTION}

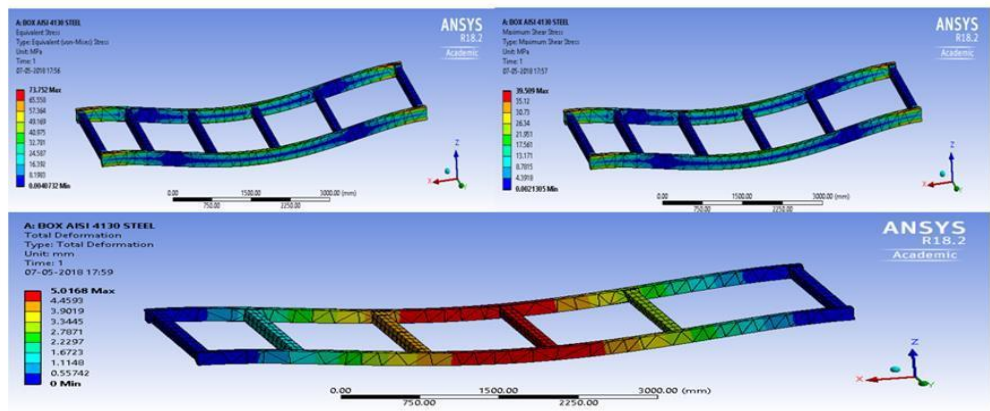

5. FOR AISI A304 STAINLESS STEEL WITH BOX SECTION

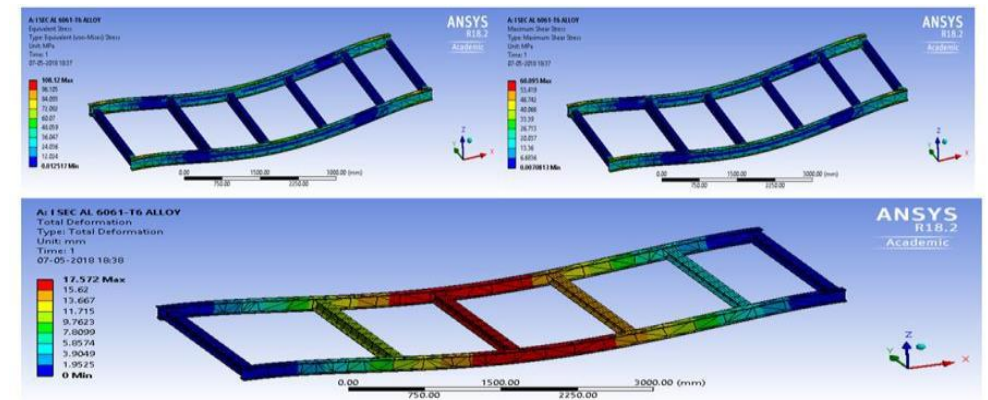

6. FOR AL 6061-T6 ALLOY WITH BOX SECTION

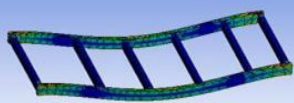

$-1-$
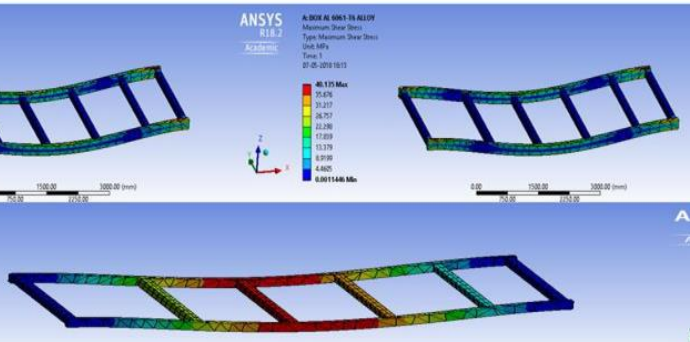

Structural analysis of I C/S kind of Stepladder Chassis

\section{FOR AISI 4130 STEEL WITH I SECTION}

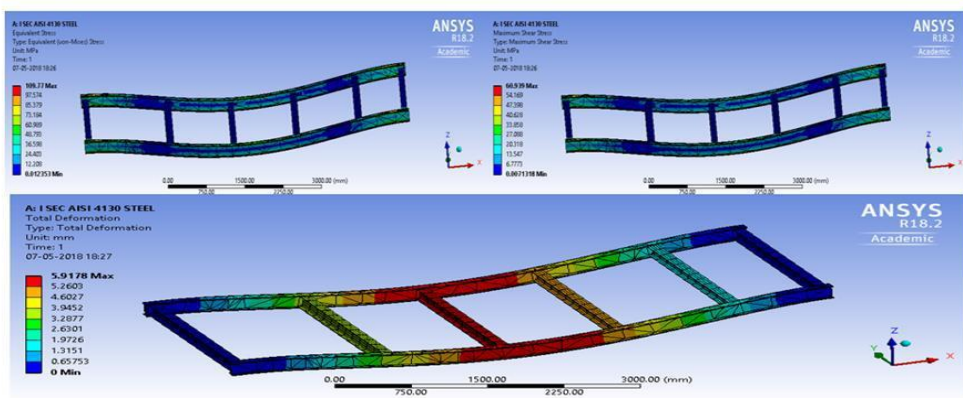

8. FOR AISI A304 STAINLESS STEEL WITH I SECTION

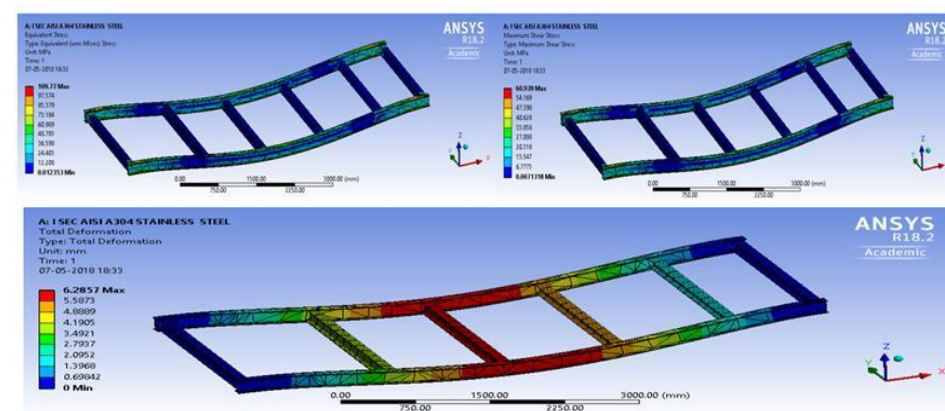

9. FOR ALUMINIUM 6061-T6 ALLOY WITH I SECTION

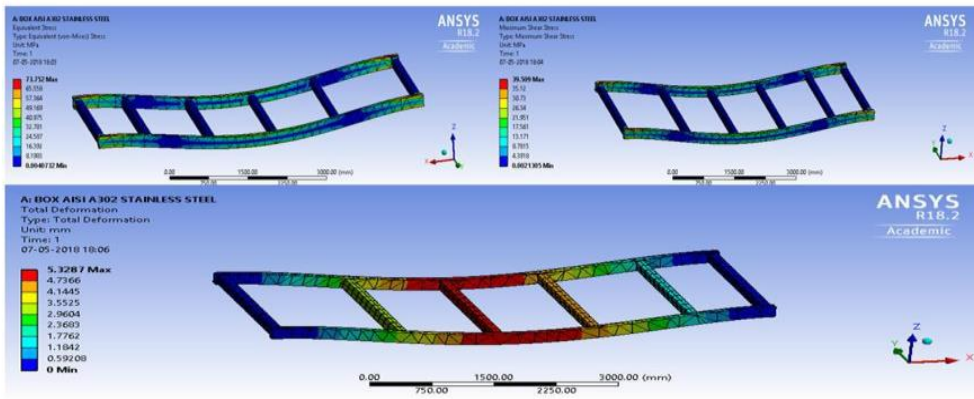

I. RESULTS AND DISCUSSION

FE Values for C Cross-Section kind of Step ladderChassis

\begin{tabular}{|l|l|c|l|}
\hline Material & $\begin{array}{l}\text { Von } \\
\text { mises } \\
\text { stress } \\
(\mathrm{Mpa})\end{array}$ & $\begin{array}{c}\text { Max Shear Stress } \\
(\mathrm{Mpa})\end{array}$ & $\begin{array}{l}\text { Deformation } \\
(\mathrm{mm})\end{array}$ \\
\hline $\begin{array}{l}\text { AISI 4130 } \\
\text { Steel }\end{array}$ & 340.78 & 196.28 & 5.62 \\
\hline $\begin{array}{l}\text { AISI A304 } \\
\text { Stainless } \\
\text { Steel }\end{array}$ & 357.81 & 206.10 & 6.09 \\
\hline $\begin{array}{l}\text { Aluminum } \\
\text { alloy 6061- } \\
\text { T6 }\end{array}$ & 443.6 & 253.39 & 11.27 \\
\hline
\end{tabular}


FE Values for I Cross-Section kind of Step ladderChassis

\begin{tabular}{|l|l|c|l|}
\hline Material & $\begin{array}{l}\text { Von } \\
\text { mises } \\
\text { stress } \\
\text { (Mpa) }\end{array}$ & $\begin{array}{r}\text { Max Shear } \\
\text { Stress } \\
\text { (Mpa) }\end{array}$ & $\begin{array}{l}\text { Deformation } \\
(\mathrm{mm})\end{array}$ \\
\hline $\begin{array}{l}\text { AISI 4130 } \\
\text { Steel }\end{array}$ & 109.77 & 60.93 & 5.91 \\
\hline $\begin{array}{l}\text { AISI A304 } \\
\text { Stainless } \\
\text { Steel }\end{array}$ & 109.78 & 60.94 & 6.28 \\
\hline $\begin{array}{l}\text { Aluminum } \\
\text { alloy 6061- } \\
\text { T6 }\end{array}$ & 108.12 & 60.09 & 17.57 \\
\hline
\end{tabular}

FE Values for Rectangular Box Cross Section kind of Step ladder Chassis

\begin{tabular}{|l|l|c|l|}
\hline Material & $\begin{array}{l}\text { Von } \\
\text { mises } \\
\text { stress } \\
\text { (Mpa) }\end{array}$ & $\begin{array}{r}\text { Max Shear } \\
\text { Stress } \\
\text { (Mpa) }\end{array}$ & $\begin{array}{l}\text { Deformation } \\
(\mathrm{mm})\end{array}$ \\
\hline $\begin{array}{l}\text { AISI 4130 } \\
\text { Steel }\end{array}$ & 73.75 & 39.50 & 5.01 \\
\hline $\begin{array}{l}\text { AISI A304 } \\
\text { Stainless } \\
\text { Steel }\end{array}$ & 73.75 & 39.51 & 5.32 \\
\hline $\begin{array}{l}\text { Aluminum } \\
\text { alloy 6061- } \\
\text { T6 }\end{array}$ & 73.60 & 40.13 & 14.85 \\
\hline
\end{tabular}

\section{CONCLUSIONS}

1. Rectangular Box section shows high strength compared C and I Cross-section kind of Stepladder Chassis.

2. AISI 4130 Steel material shows least deformation in all three cross sections.

3. The Rectangular Box C/S shows less deflection, Vonmises (Equivalent) stresses and Max Shear stresses i.e., $5.01 \mathrm{~mm}, 73.50 \mathrm{mpa} \& 39.50 \mathrm{mpa}$ respectively.

4. Shear stresses are lowest in Aluminum alloy 6061-T6 and maximum in AISI 4130 steel with given boundary circumstances.

5. The best cross-section for chassis is $\mathrm{C} \mathrm{C/S}$ because it gives economic effectiveness and best material among three is AISI A 304 Stainless steel because it gives high corrosion resistant with slightly more stress and deformation values of AISI 4130 Steel.
6. Design is safe under given loading conditions.

\section{FUTURE SCOPE}

7. Same work can be carried out by varying thickness in this geometry however standard dimension for $\mathrm{c}$ section is given as $210 * 76 * 6$.

8. Present work is done on low capacity truck and it can be carried out for medium and heavy capacity truck.

\section{REFERENCES}

1. V. Deepanjali, A. Hari Kumar, (January 2016) "Design \& analysis of automobile chassis", International journal of engineering science and innovative technology (ijesit), volume 5, issue 1, (pp 187-196).

2. Abhishek Singh, (February 2014) "Structural Analysis of Stepladder Chassis for Higher Strength", International Journal of Emerging Technology and Advanced Engineering, ISSN: 2250-2459, Volume 4, Issue 2, (pp 253-259).

3. Patel Vijaykumar, (May 2012) "Structural Analysis of Automotive Chassis Frame and Design Modification for Weight Reduction", International Journal of Engineering Research \& Technology, ISSN: 2278-0181, Volume 1, Issue 3, (pp 1-6).

4. Vishal Francis, (April 2014) "Structural Analysis of Stepladder Chassis Frame for Jeep Using ANSYS", International Journal of Modern Engineering Research, ISSN: 2249- 6645, Volume 4, Issue 4, (pp 40-47).

5. Monika S. Agarwal, (December 2013) "Finite Element Analysis of Truck Chassis", International Journal of Engineering Sciences \& Research, ISSN: 2277-9655, (pp 1949-1956). 